\title{
Effect of Camel Milk Fortified with Dates in Ice Cream Manufacture on Viscosity, Overrun, and Rheological Properties during Storage Period
}

\author{
S. A. Salem ${ }^{1,2}$, Fardous M. ${ }^{3}$, Meead G. H. El-Rashody ${ }^{3}$ \\ ${ }^{1}$ Food Science \& Human Nutrition Department, Faculty of Agriculture and Veterinary Medicine, Qassim University, \\ Buraydah, KSA \\ ${ }^{2}$ Dairy Science \& Technology Department, Faculty of Agriculture, Alexandria University, Alexandria, Egypt \\ ${ }^{3}$ Nutrition and Food Science Department, Faculty Designs and Home Economics, Qassim University, Buraydah, KSA \\ Email: samirsalem51@yahoo.com
}

How to cite this paper: Salem, S.A., Fardous, M. and El-Rashody, M.G.H. (2017) Effect of Camel Milk Fortified with Dates in Ice Cream Manufacture on Viscosity, Overrun, and Rheological Properties during Storage Period. Food and Nutrition Sciences, 8, 551-564.

https://doi.org/10.4236/fns.2017.85038

Received: March 8, 2017

Accepted: May 19, 2017

Published: May 22, 2017

Copyright (c) 2017 by authors and Scientific Research Publishing Inc. This work is licensed under the Creative Commons Attribution International License (CC BY 4.0).

http://creativecommons.org/licenses/by/4.0/

\begin{abstract}
The effect of using camel milk with 2 dates types (Sokary \& Al-Khalas), in 3 forms (paste, pieces, and molasses), with 2 different concentrations (5\% \& $10 \%$ ) in the manufacturing of ice cream on its viscosity, overrun\%, rheological and melting properties during storage period up to 60 days at $-18^{\circ} \mathrm{C}$ was studied. It was noticed that there are higher mean of viscosity values (cp) when using "Al-khalas" dates paste $5 \%$ and $10 \%$ followed by samples with "sokary" paste then samples with molasses in ice cream samples compared to those with added date's pieces of either "Sokary" or "Al-khalas". There are significant differences of overrun values between all treatments and samples with the added date paste of either "sokary" or "Al-khalas" which recorded the lowest values. Increased melting resistance and good qualities as heat shock and melting properties were significantly better for the samples with added dates pieces or paste unlike the molasses. The storage effect is obvious decline, especially when using dates molasses.
\end{abstract}

\section{Keywords}

Camel Milk, Dates, Ice Cream, Viscosity, Overrun, Melting Properties, Heat Shock, Storage Period

\section{Introduction}

Ice cream quality depends on many factors including the type of milk used in the preparation mix as it plays a key role in the product characteristics, and the physical properties of the mixture of ice cream resulting from different manufacturing methods which could change its texture and thus its physical appear- 
ance [1]. The ice cream industry is a relatively complicated process with successive steps that affect the structure and content of microbial involvement or affect the overall quality of ice cream [2] and can be seen as commenting greasy by air and water in the sugar center and protein solution [3], As well as the increase in the amount of whey protein in the milk in the emulsion face oil/water lowers the surface tension and increases the viscosity of mixture; resulting in the production of dry ice cream [4], also, the storage temperature, and is currently the industry specifications for the storage of ice cream .

Méndez and Goff [5] studied the effect of colloidal interactions to prepare ice cream that is high in unsaturated fat, and they found that it reduces the quality of which contain saturated fat. Total solids in a mixture of solid ice cream directly affects the size and distribution of ice crystals [6] as the lower solids in the ice cream the broader ice crystals formed [7].

Freezing point of the mixture of ice cream also is directly related to the concentration of the components of the mixture in solution [8], where it mainly lowers by increasing the concentration of sugar, and the addition of other soluble components to the main mixture. The type and level of fat and the level of dairy solids non-fat (MSNF) used in the mixture have a clear impact on the properties of ice cream product [9] [10].

The global demand for frozen dairies raises the necessity for increasing their production from an available source as camel milk, in addition to its high nutritional and health value. Camels and their dairy products are considered as a good dietary source for humans in many parts of the world because they contain all the essential nutrients.

The main source of Saudi Arabia's production of camel milk is from private farms where it is consumed as milk only. Recently, pasteurized camel milk appeared in the local markets but in a very limited scale. Moreover, there were many previous attempts to manufacture other forms of dairy products from camel milk.

The possibility of producing Ice cream from camel milk with acceptable quality by using a mixture of cream and camel milk solids not fat at different levels were studied by [11]. They have been studying the effect of fat content and nonfat solids and the final acceptance of the product. Researches have also shown that camel milk has many useful recipes for consumers in many parts of the world for the treatment of many diseases [12] [13] [14] showed that the whey proteins in camel milk differ than bovine milk in resistance to the denaturation point; which differs in camel milk.

Therefore, the aim of this study is to determine the viscosity, overrun, rheological and melting properties of ice cream made from camel milk with different types and ratios of dates during the storage period of 60 days at $-18^{\circ} \mathrm{C}$.

\section{Materials and Methods}

\subsection{Materials}

The ingredients of ice cream mix included are camel's milk obtained from "Farm 
College of Agriculture and Veterinary Medicine," Qassim University. and homogenized pasteurized cow cream", fat 30\%, from the sale of food Buraidah centers, Qassim region, while skim milk powder, granulated can sugar, glucose, gelatin, vanilla and emulsifiers (Egg yolk) were obtained from the local markets in Buraidah, Qassim. Also, dates "Al-khalas and sokary both full dates, dates paste" date's molasses, Naded Dates Factory, Buraidah, Qassim region. Calculations of the composition and prepare of the ice cream samples according to Salem et al. [15], as following: Two dates types (Sokary \& Al-khalas) in three forms (full dates, dates paste" date's molasses) with two different concentrations (5\% \& $10 \%)$ were used in manufacture of eleven treatments of ice cream.. When add date paste and molasses dates, it must be added at the end of the heating stage to ensure its spread in the mixture (5\% \& 10\%) of each type, but when used a pieces dates added after cooling and aging and with rates (5\% \& 10\%) for each type. All treatments sample stored to two months at $-18^{\circ} \mathrm{C}$.

\subsection{Methods}

\subsubsection{Viscosity}

Measuring the apparent viscosity of the mixtures of ice cream at a temperature values $\left(20^{\circ} \mathrm{C} \pm 1^{\circ} \mathrm{C}\right)$ using a Brookfield Programmable Rheometer Model (RVDV-III Ultra, Brookfield Engineering Laboratories, Stoughtm, MA, USA). Using LV spindle No. 2 at RPM $=47$ roll every 5 seconds to 2 minutes. Use Rheocalc software program (Ver.2.5, Brookfield Engineering Laboratories, Inc. To assemble the apparent viscosity values according to Metwally, [16] with some modifications.

\subsubsection{Overrun}

Measuring cup fixed weight of mixture cool before whipping in order to calculate the overrun, and to measure the viscosity. Then, the mixture was put in the cooling machine and whipped in ICE30BCE type, Cuisinart Company even fail completely blended, automatically controlled to stop whipping upon the arrival of the ice cream to the point of whipping required, this process leads to a partial freeze rapid mixture, air integration in the mixture or the so-called overrun, Fayed et al. [17]. The ice cream filling process manually in plastic cups lid capacity $(150 \mathrm{ml})$. Then weighed a fixed size (cup) of the product after whipping to calculate the overrun\%. After filling ice cream containers are stored at $\left(-18^{\circ} \mathrm{C}\right)$ for (24 hours) prior to study the rheological properties. Samples are taken from each treatments (three samples) after (1, 30, 60 days) of freezing and storage.

To estimate the overrun $\%$ at accordance with the method of [10] and the following equation was used to calculate rents \%:

Overrun $\%=\frac{\text { Weight and volumetric unit of the mixture }- \text { the same unit weight of the frozen product }}{\text { The same unit of the gross weight of the freezer }} \times 100$

\subsubsection{Rheological and Melting properties}

The rheological properties and the properties of the melting of ice cream after (1 Day) and (30 days) and (60 days) from the freeze were studied. The contents of 
the cup put on a stainless steel mesh, and below the graduated cylinder at room temperature $\left(20^{\circ} \mathrm{C}-25^{\circ} \mathrm{C}\right)$, which allow for frozen packs to melt for $(45 \mathrm{mi}$ nutes), and calculates the First Time, which goes on the descent of the first drop after melt minute. Second, quantity by $\mathrm{ml}$ collected in ( 45 minutes), and the results are recorded in accordance with the method of Mathur and Srinivasan, [18]. Measuring thermal Heat shock of ice cream: Thermal shock is measured according to [19], two cubs of ice cream taken $\left(-18^{\circ} \mathrm{C}\right)$ twice a day, and reserved at $\left(23^{\circ} \mathrm{C}-25^{\circ} \mathrm{C}\right)$ for $(30$ minutes), and then re-frozen again, and this work was repeated five consecutive days. All samples that underwent thermal shock tests based on the speed of melting, and harshness in the textures, and the occurrence of contraction, sanding, and deposition dates.

\subsubsection{Statistical Analysis}

In accordance with the system of statistical analysis, [20] and LSD test-MannWhitney test for two independent samples test and one way ANOVA.

\section{Results and Discussion}

\subsection{Viscosity}

Figure 1 shows the average viscosity values in the mixtures of ice cream for different treatments, and it turned out that the viscosity values (CP) of samples with added paste Al-khalas (5\% \& 10\%) recorded significantly higher values, followed by samples with the paste pass sokary at rates (5\%) and (10\%), followed by samples with added molasses dates by $(10 \% \& 5 \%)$, respectively.

While the viscosity of treatments with added pieces of dates had values less than the control sample, and that there were significant differences between the treatments, it is probably due to not adding pieces of dates only after the whipping and freezing, and the measured viscosity was before the whipping process,

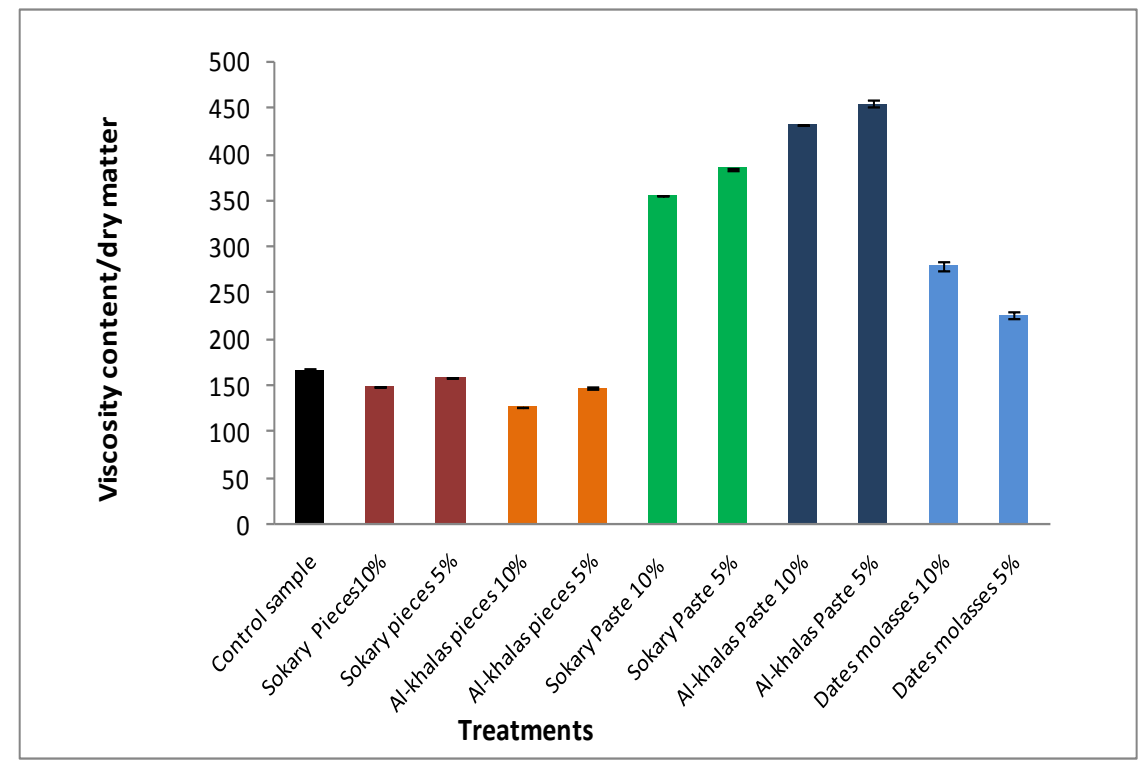

Figure 1. Average viscosity values of ice cream samples of different Treatments. 
and due to the less added sugars ratios, and then on viscosity, which increases with hardwood solids non-fat values, and this is consistent with what was done [11], studied the effect of different percentages of fat, total solids and solids-non fat have been where the viscosity mixtures ice cream made from camel milk, and showed that an increase of fat ratio and total solids increases the viscosity values. [10] record similar results in the same direction of the ice cream made from cow's milk, probably due to the presence of a high proportion of fiber in date paste, and it has been found that increase in the viscosity of the mixtures rich in ice cream fiber was due to both the contribution of soluble matter to the composition of aqueous phase and to the contribution of insoluble fibers to the increase of the total solids, and these affect the three dimnational conformation of the hydrated biopolymers. It has been found that an increase in viscosity is due to the increased concentration of the serum, which is due to the restoration of the water by soluble fiber [21].

Hartel [22], explained that the type and proportion of the fiber used significantly affect $(p>0.001)$ the freezing point and the molecular weights, such as the degree of total ice formation. [23] found that the addition of fiber of pulp dates naturalized as a substitute for fat led to increased viscosity, and it is probably due to the increased proportion of dissolved and the ingredients/or low molecular weight prepared fiber pulp average dates, and the proportion of these fibers. It has been found that when the fiber is soluble, this leads to enhancing viscosity and liquefaction strength of a mixture of ice cream; due to the restoring of water and destroying the molecule due to the presence of an extensive network of it as cellulose associated with water [21], they also found that increasing the material is dissolved affect very much less to increase the viscosity (although that is still a high viscosity).

Both [9] [10] recorded that the high viscosity of the mixtures of ice cream is a desirable quality; where it shared or help in whipping and body composition and good textures, and [24] explained that the size of the fat granules has great importance in estimating the viscosity of the mixture, and in this regard, the fresh camel milk appears that looks like a cow's milk naturalized, usually contains a small-size granules fat [11].

Smith et al. [25] have found that the synthetic water system of fructose and glucose are more than sucrose, and proved that the sweeteners that contain large amounts of glucose increased the installation, and they found that an increase of the changes in the arrangement of water molecules around the sugar molecules were able to bring about changes in water absorption and increase the viscosity. Use of modified starch and polysaccharides led to a clear increase in the apparent viscosity and the factors influencing them, in terms of the link with water capacity and the degree of polymerization and branching [26].

\subsection{Overrun}

Reflects the increase in overrun for ice cream the size of the output of the air overlap in the product during freezing, a technician may scale varies depending 
on the methods used and the materials involved in the installation conditions [27].

Figure 2 show average percentage of proceeds Overrun samples of various ice cream, and it became clear from the results that all added samples Dates either cut , paste or molasses and in any proportion (5\% or $10 \%)$ led to significantly decrease in the percentages of overrun than that of control sample.

Under the conditions of the test, the overrun ranged between $(22.2 \%$ $27.47 \%$ ), which is relatively low compared to the registrar in previous studies of many researchers, probably due to the use of the freeze on the batch system [28], but it is very close with the results obtained by [29], which ranged from $(22.54 \%$ - 33.33\%).

Also, it is obvious from Figure 2 that there are no significant differences in the average overrun values when adding all of the date pieces or dates molasses, while there are significant differences between them and the added date paste either sokary or Alkhalas, which recorded the lowest overrun values in all treatments, perhaps due to the high fiber in a paste ratio, resulting in a difficulty whipping process air and the introduction of plug-in during the freezing process, and this is consistent with the results of the study carried out by [11], and that the study was made adding different proportions of fat solids and solid ice cream effect, which showed that an increase of the percentage of total solids least overrun.

\subsection{Rheological Properties}

Rheological properties are one important physical quality that has to do with body, construction, softness, textures and a sense of cooling, and these qualities are the most common form of ice cream during the configuration [30]. The stability of foam ice cream has to do with the existence of creamy properties that could be improved by the presence of small air cells, and reduces the adhesion or docking [31], and low temperature during freezing accumulate fat granules and

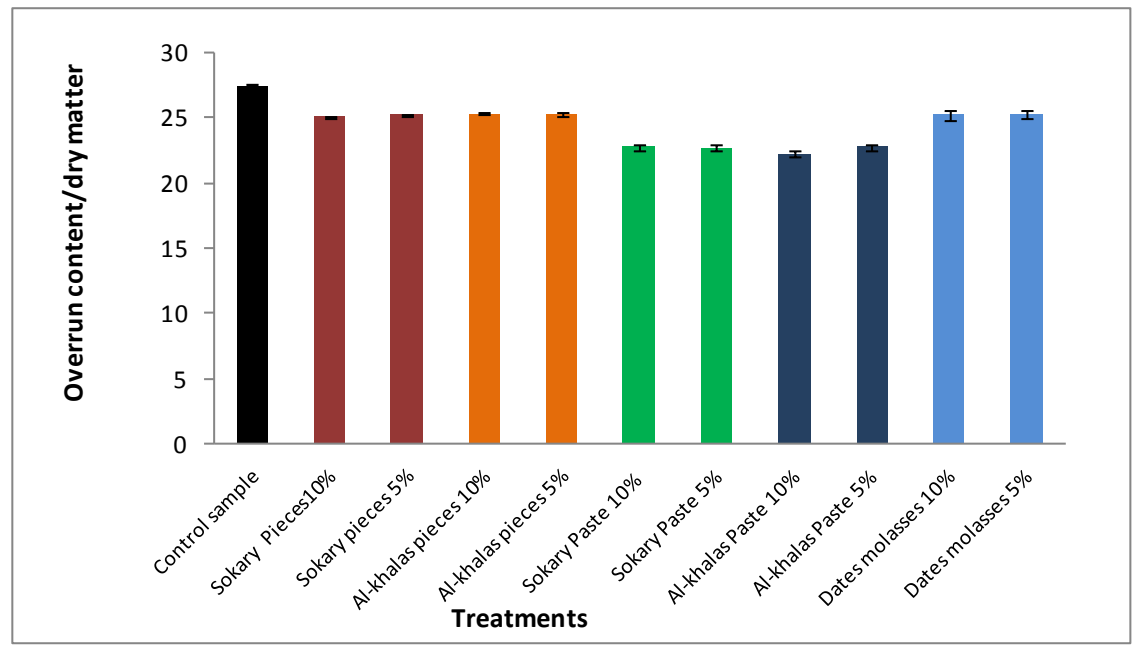

Figure 2. Average Overrun values of ice cream samples of different Treatments. 
gives the highest stability of the foam, and these changes have a significant impact on the foam, and related to the quality of the properties of ice cream, and proving by rheological measurements and tests during the liquidity melted.

\subsubsection{Melting Resistance}

Melting Resistance desirable consumer's recipe [32]. Table 1 shows the average resistance to melting and standard deviation values shows the time expressed in minutes of the descent of the first drop of liquefied ice cream of various treatments during the storage period of time (60 days).

It is clear from the results that the added cutting pass sokary or AL-khalas rates $(5 \%)$ and $(10 \%)$ or date paste either sokary or AL-khalas in the same ratios have increased the time required for melting significantly than the control sample, on the contrary added dates molasses treatments whether $(5 \%)$, or (10\%) led to the significant melting speed than other samples, after (1 day) of manufacturing and freezing, and this is probably due to the effect of the presence of fiber in the add-ons that significantly influence the proportion of frozen water in the mixtures of ice cream, as the ice formation in model systems is strongly more of a result of the decline in the proportion of solids and protein, which tends to be associated with water [33], while [22] found that the fiber ratio did not affect the percentage of water in amorphous, where depends gelling strongly along the freezing point and the proportion of the associated water.

Also it contributes to fat dramatically in the ice cream structure during freezing and whipping, through the partial formation of three-dimensional network of fatty grained homogeneous along with air bubbles and ice crystals, which is

Table 1. Average values of melting resistance expressed in time per minute for the descent of the first drop of ice cream for various treatments during the storage period for 60 days at $-18^{\circ} \mathrm{C}$.

\begin{tabular}{|c|c|c|c|}
\hline \multirow[t]{2}{*}{ Treatments } & \multicolumn{3}{|c|}{$\begin{array}{l}\text { Mean and standard deviation of the time that } \\
\text { has passed the descent of the first drop per minute }\end{array}$} \\
\hline & After 1 day & After 30 days & After 60 days \\
\hline Control sample & $31.83 \pm 0.7202^{c_{-} B C}$ & $30.46 \pm 0.0404^{\mathrm{b}-\mathrm{C}}$ & $26.21 \pm 0.1858^{a}-{ }^{B C}$ \\
\hline Sokary Pieces $10 \%$ & $31.77 \pm 0.6643^{\mathrm{b}-\mathrm{B}}$ & $30.87 \pm 0.344^{\mathrm{b}}-\mathrm{CD}$ & $26.94 \pm 0.3287^{\mathrm{a}-\mathrm{D}}$ \\
\hline Sokary pieces $5 \%$ & $32.9 \pm 0.274^{\mathrm{c}-\mathrm{DE}}$ & $30.62 \pm 0.3293^{\mathrm{b}-\mathrm{CD}}$ & $27.24 \pm 0.0153^{\mathrm{a}-\mathrm{D}}$ \\
\hline Al-khalas pieces $10 \%$ & $32.35 \pm 0.0451^{c_{-}{ }_{B} B C D E}$ & $31.35 \pm 0.0252^{\mathrm{b} \_D E F}$ & $26.97 \pm 0.3659^{\mathrm{a}-\mathrm{D}}$ \\
\hline Al-khalas pieces $5 \%$ & $32.88 \pm 0.346^{\mathrm{c}-\mathrm{CDE}}$ & $31.08 \pm 0.4219^{\mathrm{b}-\mathrm{CD}}$ & $25.89 \pm 0.362^{\mathrm{a}-\mathrm{B}}$ \\
\hline Sokary Paste $10 \%$ & $33.3 \pm 0.05^{\mathrm{c}-\mathrm{E}}$ & $31.93 \pm 0.4095^{\mathrm{b}-\mathrm{EFG}}$ & $27.22 \pm 0.02^{\mathrm{a}-\mathrm{D}}$ \\
\hline Sokary Paste 5\% & $33.38 \pm 0.0681^{\mathrm{c}_{-} \mathrm{E}}$ & $32.32 \pm 0.2754^{\mathrm{b}-\mathrm{G}}$ & $27.32 \pm 0.0764^{\mathrm{a}-\mathrm{D}}$ \\
\hline Al-khalas Paste $10 \%$ & $33.35 \pm 0.4843^{c_{-} \mathrm{E}}$ & $32.09 \pm 0.0854^{\mathrm{b}-\mathrm{FG}}$ & $26.86 \pm 0.3272^{\mathrm{a}-\mathrm{CD}}$ \\
\hline Al-khalas Paste 5\% & $32.08 \pm 0.0764^{c}{ }_{-}{ }^{B C D}$ & $31.28 \pm 0.1258^{\mathrm{b}-\mathrm{DE}}$ & $26.09 \pm 0.0777^{\mathrm{a}-\mathrm{B}}$ \\
\hline Dates molasses $10 \%$ & $27.12 \pm 0.1082^{c-A}$ & $23.18 \pm 0.1756^{\mathrm{b}-\mathrm{B}}$ & $18.26 \pm 0.2471^{\mathrm{a}-\mathrm{A}}$ \\
\hline Dates molasses $5 \%$ & $26.11 \pm 0.0945^{\mathrm{c}-\mathrm{A}}$ & $22.06 \pm 0.1097^{\mathrm{b}-\mathrm{A}}$ & $18.08 \pm 0.0681^{\mathrm{a}-\mathrm{A}}$ \\
\hline
\end{tabular}

The sample size of $n=3$ and the level of the significance 0.05 . The comparison between per class has components of symbols a, b, c. The comparison between per column has components of symbols A, B, C. 
responsible for the drought in the product as well as a melted textures and softness in the resistance of the frozen product [1] [34] [35] [36].

As stated [37] that the lipid pool level is affected only along a simple parallel with the increase in the level of the emulsion.

The melting resistance has a strong relationship with the overrun, and this shows that the ice cream containing more air has a high resistance to melting and gives a melting lower part [11]. Also, showed that the melting resistance of ice cream gradually increases with the increase in fat content, but with increasing non-fatty solids (13\%), the melting resistance increases with increase fat ratio from $4 \%-12 \%$.

It is also clear from the Table 1 that the storage on $\left(-18^{\circ} \mathrm{C}\right)$ for a period of $(60$ days) had a significant effect on melting resistance; dropping melting resistant to all samples up to the storage period, and the decline was evident in treatments with added molasses dates. On the whole, the first drop down from the ice cream in all treatments took a long time, ranging from (26.11 to 33.38 minutes), this is considered to be a good indicator of all treatments on the quality of output; where this is an ideal time. Figure 3 shows also another measure of resistance to melting; where an estimated quantity of the molten was measured with mellitre within 45 minutes of block ice-cream for all treatments, and also during storage period (60 days) at $\left(-18^{\circ} \mathrm{C}\right)$.

The results also indicated that the quantity of molten samples with added molasses dates (5\%), or (10\%) were higher melting, followed by samples with added paste AL-khalas then cut sokary and pieces of AL-khalas compared to the control sample $(\mathrm{p}<0.05)$. Storage led to increased melting significantly, and the most melted samples were the ones with added molasses dates, and also noted that there are no significant differences between the various treatments at the end of the storage period (60 days) except for samples with added molasses dates and the control sample, and also the molten amounts ranged through (45 min)

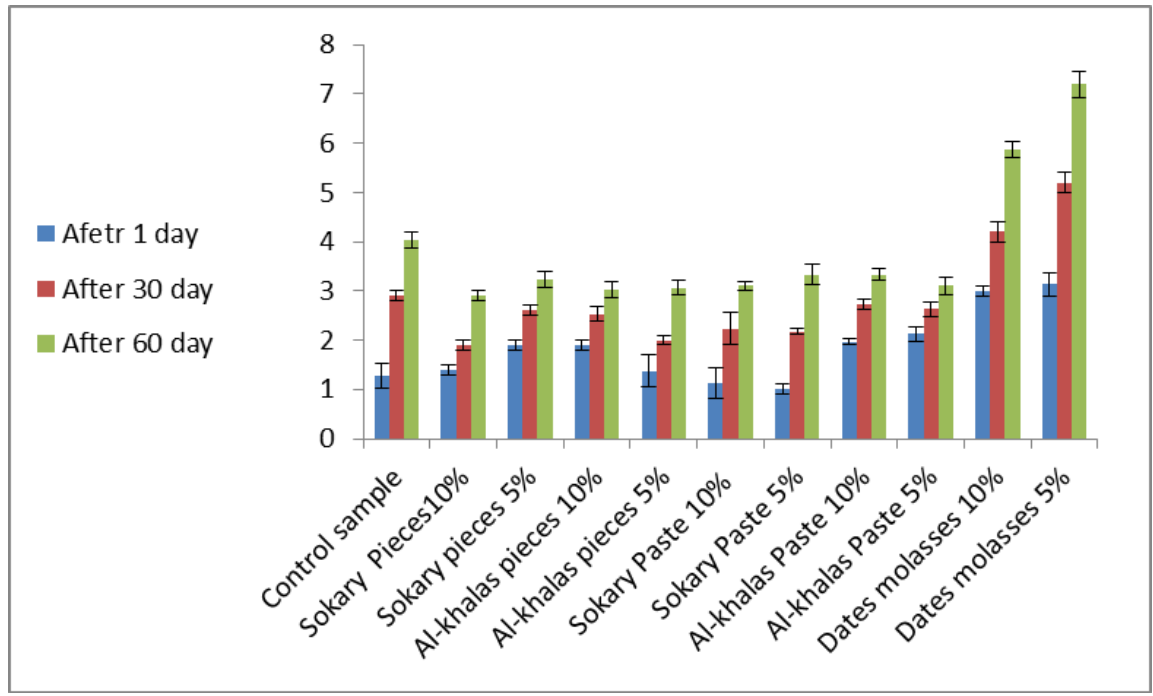

Figure 3. Average values of melting resistance expressed in time per minute for the descent of the first drop of ice cream for various treatments during the storage. 
between ( 1 to $3.13 \mathrm{ml}$ ) of the samples after one day of manufacturing, and between $(2.9$ to $7.2 \mathrm{ml})$ at the end of the storage period, which is in the range of $(1.45 \%)-(3.6 \%)$, and this confirms the quality of the final product, both after manufacturing or after storage for two months.

Cottrel et al. [38] has mentioned that fused the production of small components, and that the melting rate $(10 \%-40 \%)$ is considered acceptable when they are allowed to block melting through two hours at $25^{\circ} \mathrm{C}$. [39] Stated that a good understanding of the relationship between milk protein interactions and many sugars and the stability of the emulsion probably improves the design composition of ice cream equations; because the properties of the final product will partly depend on these interactions between molecules. As also [40] mentioned that the composition and stability of the spread of colloidal systems rely on the environmental conditions such as ( $\mathrm{pH}$, temperature degree and ionic strength) and the concentration and the proportion of polymers when there are interactions between proteins and polysaccharide.

There are many factors that affect the melting behavior including overrun [41] and the percentage of fat and fat substitutes [27], as well as milk type, [42]. The making of good ice cream need to carefully control each of the overrun and the size and distribution of air cells; therefore always neglect the distribution of air cells during the manufacturing process and storage of ice cream. Also, there are many factors affecting the development of airway cells in ice cream [43], and at least aerobic cells brings down the temperature; as a result of viscosity of face serum. [44] partially rely on low temperatures during the latter stages leading to a form of unregulated air cells, which leads to overlapping air pockets storage. It has been found that an increase in the viscosity of the facial serum [45] or lowering storage temperature [44] were ways to reduce liquidity [46]. [40] has been found that the change in the air cells and change the docking a result of increased overrun in the ice cream which makes it a somewhat softer and more resistant to melting; as meaning a slower melting rate. [47] noted that the average size of ice crystals and air cells and overrun were not significantly altered by protein source or mixing or concentration, and they also found that the latter affects the overlap emulsion; leading to molecular differences in stiffness and rate of melting.

In general, the melting rate is inversely proportional to the extent of non-fat stability (lack of stability), and indicate that an increase in a protein that is found in the ice cream didn't affect the stability of the fat, and thus to increase the melting rate.

[48] found also that there are several factors that affect the melting and portability rate of heat to penetrate the ice cream (Thermal diffusivity), and also higher overrun reduces melting; because it reduces the ability of heat to penetrate the ice cream, so in these treatments overrun are broadly similar, and therefore it has no effect on melting.

The increase in the fat content lead to lower melting rate, and suggests that the gathering of fat globules can belay air bubbles in the of ice cream body, and 
thus reduce the melting rate, so the high fat content reduces the size of the ice crystals, and by increasing the ice crystals it will make it harder. [11] also found that the melting resistance increased with the increase of viscosity and has a strong relationship with the overrun, and that melting resistance increased with the increase of fat percentage, but with increasing non-fat solids to $13 \%$, a decrease in the melting resistance will occur with increase in the fat percentage from $4 \%-12 \%$.

The particles size and the stability of emulsifying with larger particles increase the melting resistance, and that the particle size has an inverse relationship with Overrun, with increasing particle size the susceptibility of proteins on the surface of the air-water is reduced more often [5]. Also [49] found that the melting rate of the samples of ice cream treated with (hydrolyzed lactose) was higher than the solution analyzed having (50\%) by lactase or invertase or their mixture, and unexpectedly found that the melting of samples analyzed in rate (50\%) by a mixture lactase-invertase was not significantly different from the control sample.

[50] found also that the increasing hydrolysis of lactose due to decrease the melting resistance, while [19] found that substituting solids of the sweet whey (11\%) lactose hydrolysis (79\%) instead of (6\%) milk solids non-fat and 5\% sucrose, the melting time was not significantly changed from the control sample, and proved that the decomposition of sugars did not lead to significant increase in the degree of melting, and that proves assist sharp decline in temperature.

\subsubsection{Heat Shock}

Control of crystallization processes is one of the most important factors affecting the properties of stability and organoleptic properties of frozen products [51], and ice crystals are considered an important component of the last freeze system [52].

Table $2 \&$ Table 3 shows the changes in the speed of melting, shrinking, and sanding, the formation of crystals ices, and the changes that occur in dates added during the measurement of thermal shock, as well as illustrates these qualities after a period of storage temperature $\left(-18^{\circ} \mathrm{C}\right)$ for a period of (60 days).

It is clear from the results that the samples with added cut sokary dates (10\%) recorded after one day of the freeze were similar to the sample control after the test, but it fastened the slow melting, and samples with (5\%) cut sokary dates appeared to have minimal shrinkage with the slow melt.

After a month of storage began to defect deposition of dates simple sedimen-

Table 2. Qualities of sampling various Treatments for ice cream after the Heat shock Test.

\begin{tabular}{|c|c|c|c|c|}
\hline $\begin{array}{c}\text { 5/Dates } \\
\text { Precipitation }\end{array}$ & 4/Sanding & 3/Shrinkage & $\begin{array}{l}2 / \text { Ice-crystals } \\
\text { roughness textures }\end{array}$ & $\begin{array}{l}1 / \text { Speed } \\
\text { melting }\end{array}$ \\
\hline A. Did not & A. Did not occur & A. Did not happen & A. Non formed & A Not affected \\
\hline B. Simple & B. Simple & B. Simple occurred & B. Formed simple & B. Slow \\
\hline C. Medium & C. Moderately occurred & C. Moderately occurred & C. Formed medium & C. Medium \\
\hline D. High & D. Highly occurred & D. Highly occurred & D. Formed high & D. Fast \\
\hline
\end{tabular}


Table 3. Heat Shock of Ice cream samples.

\begin{tabular}{|c|c|c|c|c|c|c|c|c|c|c|c|}
\hline \multirow[b]{2}{*}{ 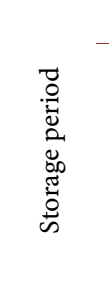 } & \multicolumn{11}{|c|}{ Treatments } \\
\hline & $\begin{array}{l}\overrightarrow{0} \\
\stackrel{0}{0} \\
0\end{array}$ & 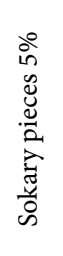 & 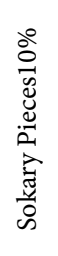 & 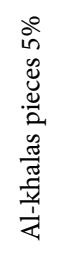 & 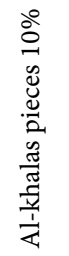 & 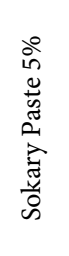 & 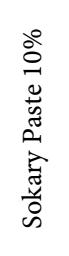 & 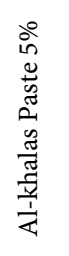 & 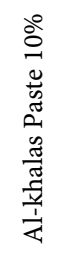 & 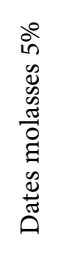 & 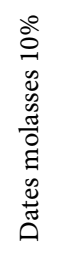 \\
\hline \multirow{5}{*}{$\begin{array}{l}\text { After } \\
1 \text { day }\end{array}$} & A-1 & B-1 & B-1 & A-1 & A-1 & A-1 & B-1 & B-1 & $\mathrm{C}-1$ & C-1 & A-1 \\
\hline & A-2 & A-2 & A-2 & A-2 & A-2 & B-2 & A-2 & A-2 & B-2 & B-2 & B-2 \\
\hline & A-3 & A-3 & B-3 & A-3 & A-3 & A-3 & B-3 & A-3 & A-3 & A-3 & A-3 \\
\hline & A- 4 & A- 4 & A- 4 & A- 4 & A- 4 & A-4 & A-4 & A- 4 & A-4 & A- 4 & A- 4 \\
\hline & A-5 & A-5 & A-5 & A-5 & A-5 & A-5 & A-5 & A-5 & A-5 & A-5 & A-5 \\
\hline \multirow{5}{*}{$\begin{array}{c}\text { After } 30 \\
\text { days }\end{array}$} & A-1 & B-1 & B-1 & A-1 & A-1 & A-1 & B-1 & B-1 & D-1 & $\mathrm{C}-1$ & A-1 \\
\hline & A-2 & A-2 & B-2 & B-2 & C-2 & B-2 & B-2 & B-2 & $\mathrm{C}-2$ & C-2 & C-2 \\
\hline & A-3 & A-3 & A-3 & A-3 & A-3 & A-3 & A-3 & A-3 & A-3 & A-3 & A-3 \\
\hline & A- 4 & A- 4 & A- 4 & A-4 & A-4 & A-4 & A-4 & A-4 & A-4 & A-4 & A- 4 \\
\hline & A-5 & B-5 & B-5 & A-5 & B-5 & A-5 & A-5 & A-5 & A-5 & A-5 & A-5 \\
\hline \multirow{5}{*}{$\begin{array}{c}\text { After } 60 \\
\text { days }\end{array}$} & A-1 & A-1 & A-1 & A-1 & A-1 & A-1 & $\mathrm{C}-1$ & A-1 & D-1 & $\mathrm{C}-1$ & A-1 \\
\hline & B-2 & B-2 & $\mathrm{C}-2$ & B-2 & B-2 & $\mathrm{C}-2$ & A-2 & $\mathrm{C}-2$ & $\mathrm{C}-2$ & C-2 & C-2 \\
\hline & A-3 & A-3 & A-3 & B-3 & A-3 & A-3 & A-3 & A-3 & A-3 & A-3 & A-3 \\
\hline & A- 4 & A-4 & A- 4 & A-4 & A-4 & B-4 & A-4 & A- 4 & A-4 & A-4 & A- 4 \\
\hline & A-5 & A-5 & B-5 & B-5 & B-5 & A-5 & A-5 & A-5 & A-5 & A-5 & A-5 \\
\hline
\end{tabular}

tation and configure a simple ice crystals increased in the samples with added cutting pass with ratio (5\%) after (60 days) of storage, while the samples are added to it a cutting pass Al-khalas (5\%), (10\%) recorded good qualities after one day of storage, some of the small and medium ice crystals appeared after one month and two months of storage, the simple precipitation for dates. It also clearly records the characteristics of this product thermal shock during storage for two months. The results also showed that the use of sokary date paste or Alkhalas (5\%) and (10\%), had the some observations both after (1) or (30 or 60 days), such as the slow melting, or a slight contraction, and the use of paste of dates by (5\%) was better. Samples with added dates molasses (10\%) recorded less notes than (5\%) after a heat shock and after storage for a period (60 days), although the observations recorded do not represent a danger to recipes of ice cream in terms of composition of medium degree of crystals ice and did not record any of the samples defect sanding throughout the storage period of time (60 days).

\section{Conclusion}

It was noticed that there is higher mean of viscosity values (cp) and lower overrun percentage when using dates paste and molasses in ice cream samples compared to those with added dates pieces of either Sokary or Al-khalas. Increased melting resistance and good qualities as heat shock were significantly better for the samples with added dates pieces or paste unlike the molasses. This confirms the quality of the product in all its dealings and carries it to heat shock during storage, and the validity and acceptance of the public, especially the control 
sample.

\section{References}

[1] Goff, H.D. (1997) Colloidal Aspects of Ice Cream-A Review. International Dairy Journal, 7, 363-373.

[2] Robinson, R.K. (1981) The Microbiology of the Milk Products. In: Dairy Microbiology, Vol. 2, Apphed Science Publishers, London and New York.

[3] Frost, M.B., Heymann, H., Bredie, W.L.P., Djksterhuis, G.B. and Martens, M. (2005) Sensory Measurement of Dynamic Flavor Intensity in Ice Cream with Different Fat Levels and Flavorings. Food Quality and Preference, 16, 305-314.

[4] Goff, H.D., Freslon, B., Sahagian, M.E., Hauber, T.D., Stone, A.P. and Stanley, D.W. (1995) Structural Development in Ice Cream-Dynamic Rheological Measurements. Journal of Texture Studies, 26, 517-536. https://doi.org/10.1111/j.1745-4603.1995.tb00801.x

[5] Méndez, V. and Goff (2011) Enhancement of Fat Colloidal Interactions for the Preparation of Ice Cream High in Unsaturated Fat. International Dairy Journal, 21, 540-547.

[6] Flores, A.A. and Goff, H.D. (1999) Ice Crystal Size Distributions in Dynamically Frozen Model Solutions and Ice Cream as Affected by Stabilizers. Journal of Dairy Science, 82, 1399-1407. https://doi.org/10.3168/jds.s0022-0302(99)75366-x

[7] Donhowe, D.P., Hartel, R.W. and Bradley, R.L. (1991) Determination of Ice Crystal Size Distributions in Frozen Desserts. Journal of Dairy Science, 74, 3334-3344. https://doi.org/10.3168/jds.S0022-0302(91)78521-4

[8] Keeney, P.G. and Kroger, M. (1974) Fundamentals of Dairy Chemistry. 2nd Edition, AVI Publishing Co., Westport.

[9] Anon (1978) Confectionery and Bakery. 14-16.

[10] Arbuckle, W.S. (1986) Ice Cream. 3rd Edition, The AVI Publishing Company, INC, Westport.

[11] Abu-Lehia, Ibrahim, H.S., Ibrahim, A.L.M. and EL-Behry, M. (1989) Studies on the Production of Ice Cream from Camel Milk Products. King Saud University, Riyadh, 31-33.

[12] Wernery, U. (2003) Novel Observations on Camel Milk. In: Camel Health in Relation to Camel Milk. Proceedings of 9 th Kenya Camel Forum.

[13] Yagil, R. (1982) Camels and Camel Milk. Animal. Production and Health Paper No. 26, FAO, Rome, 26 p.

[14] Knoess, K.H. (1982) Milk Production of the Dromedary. Proceeding of the IFS Symposium Camels, Sudan, 201-214.

[15] Salem, S.A., El-Rashody, M. and Fardous, M. (2017) Some Physico-Chemical, and Sensory Properties of Ice Cream Made from Camel Milk Fortified with Date's Products. BEST Journals. IJHAMS, 5, 29-40.

[16] Metwally, A.M.M.E. (2007) Effect of Enzymatic Cross-Linking of Milk Proteins on Properties of Ice Cream with Different Composition. International Journal of Food Science \& Technology, 42, 939-947. https://doi.org/10.1111/j.1365-2621.2006.01314.x

[17] Fayed, A.E., Khalafalla, S.M. and Mohamed, R.O. (1999) Comparative Supplementations of Ice Cream Mixes by Ultra-Filtrated Skim Milk Retentate or Dried Whey Protein Concentrate. 6th Conference on Food Science and Technology, Cairo.

[18] Mathur, B.N. and Srinivasan, M. (1979) Isolation and Utilization of Proteins from 
Whey Systems of Buffalo Milk on Pilot Scale. II. Utilization of Whey Protein Isolates in Formulated Dairy Products. Journal of Food Science and Technology, 16, 47.

[19] Guy, E.J. (1980) Partial Replacement of Non Fat Milk Solids and Cane Sugar in Ice Cream with Lactose Hydrolyzed Sweet Whey Solids. Journal of Food Science, 45, 129-133. https://doi.org/10.1111/j.1365-2621.1980.tb03887.x

[20] SAS (1996) Statistical Analysis System. SAS User's Guide: Statistics. SAS Institute Inc., Cary.

[21] Soukoulis, C., Lebesi, D. and Tzia, C. (2009) Enrichment of Ice Cream with Dietary Fiber: Effects on Rheological Properties, Ice Crystallization and Glass Transition Phenomena. Food Chemistry, 115, 665-671.

[22] Hartel, R.W. (2001) Crystallization in Foods. Aspen Publishers Inc., Gaithersburg.

[23] Khalil, R.A.M. and Blassy, K.I. (2011) The Use Modified Date Pulp Fibers in Functional Low Fat Ice Cream. Egyptian Journal of Dairy Science, 39, 275-283.

[24] Sommer, H.H. (1951) The Theory and Practice of Ice Cream Making. 6th Edition, The Author, Madison, 286.

[25] Smith, D.E., Bakshi, A.S. and Lomauro, C.J. (1984) Changes in Function of Sweetener System and Whey Substitution. Milchwissenschaft, 39, 455.

[26] Soukoulis, C., Lyroni, E. and Tzia, C. (2010) Sensory Profiling and Hedonic Judgment of Probiotic Ice Cream as a Function of Hydrocolloids, Yogurt and Milk Fat Content. LWT_Food Science and Technology, 43, 1351.

[27] Karaca, O.B., Guven, M.Y., Kaya, S. and Kahyaoglu, A. (2009) The Functional, Rheological and Sensory Characteristics of Ice Creams with Various Fat Replacers. International Journal of Dairy Technology, 62, 93-99.

[28] Akalin, A.S. and Erisir, D. (2008) Effects of Inulin and Oligo Fructose on the Rheological Characteristics and Probiotic Culture Survival in Low-Fat Probiotic Ice Cream. Journal of Food Science, 78, 184-188. https://doi.org/10.1111/j.1750-3841.2008.00728.x

[29] Dertlia, E., Tokerb, O.S., Durakb, M.Z., Yilmazb, M.T., Tatlısu, N.B., Sagdicb, O. and Cankurtd, H. (2016) Development of a Fermented Ice Cream as Influenced by in Situ Exopolysaccharide Production: Rheological, Molecular, Microstructural and Sensory Characterization. Carbohydrate Polymers, 136, 427-440.

[30] Bahramparvas, M. and Mazaheri Tehrani, M. (2011) Application and Functions of Stabilizers in Ice Cream. Food Reviews International, 27, 389-407.

https://doi.org/10.1080/87559129.2011.563399

[31] Eisner, M.D., Wildmoser, H. and Windhab, E.J. (2005) Air Cell Micro Structuring in a High Viscous Ice Cream Matrix. Colloids and Surfaces A: Physicochemical and Engineering Aspects, 263, 390-399.

[32] Thompson, L.V., Reniers, D.J., Baker, L.M. and Siu, M. (1982) Succinylated Whey Protein Concentrates in Ice Cream and Instant Puddings. Journal of Dairy Science, 66, 1630-1637. https://doi.org/10.3168/jds.S0022-0302(83)81985-7

[33] Alvarez, V.B., Wolters, C.L., Vodovotz, Y. and Ji, T. (2005) Physical Properties of Ice Cream Containing Milk Protein Concentrates. Journal of Dairy Science, 88, 862871. https://doi.org/10.3168/jds.S0022-0302(05)72752-1

[34] Berger, K.G. (997) Ice Cream. In: Friberg, S.E. and Larsson, K., Eds., Food Emulsions, 3rd Edition, Marcel Dekker Inc., New York, 413-490.

[35] Tharp, B.W., Forrest, B., Swan, C., Dunning, L. and Hilmoe, M. (1998) Basic Factors Affecting Ice Cream Meltdown. In: Buchheim, W., Ed., Ice Cream: Proceedings of the International Symposium, International Dairy Federation, Brussels, 54-64. 
[36] Campbell, I.J. and Pelan, B.M.C. (1998) The Influence of Emulsion Stability on the Properties of Ice Cream. In: Buchheim, W., Ed., Ice Cream: Proceedings of the International Symposium, International Dairy Federation, Brussels, 25-36.

[37] Bolliger, S., Goff, H.D. and Tharp, B.W. (2000) Correlation between Colloidal Properties of Ice Cream Mix and Ice Cream. International Dairy Journal, 10, 303 309.

[38] Cottrell, J.I.L., Geoffrey, P. and Phillips, G.O. (1979) Assessment of Polysaccharides as Ice Cream Stabilizers. Journal of the Science of Food and Agriculture, 30, 10851088. https://doi.org/10.1002/jsfa.2740301111

[39] Cheng, J., Ma, Y., Li, X., Yam, T. and Cui, J. (2015) Effects of Milk Protein-Polysaccharide Interactions on the Stability of Ice Cream Mix Model Systems. Food Hydrocolloids, 45, 237-336.

[40] Corredig, M., Sharafbafi, N. and Kristo, E. (2011) Polysaccharide-Protein Interactions in Dairy Matrices, Control and Design of Structures. Food Hydrocolloids, 25, 1833-1841.

[41] Sofjan, R.P. and Hartel, R.W. (2004) Effects of Overrun on Structural and Physical Characteristics of Ice Cream. International Dairy Journal, 14, 255-262.

[42] Correia, R., Magalhaes, M., Pedrini, M., Cruz, A. and Clementino, I. (2008) Sorvetes elaborados com leite caprino e bovino: composição química e propriedades de derretimento. Revista Ciência Agronômica, 39, 251-256.

[43] Marshall, R.T. and Arbuckle, W.S. (1996) Ice Cream. 5th Edition, Chapman and Hall, London. https://doi.org/10.1007/978-1-4613-0477-7

[44] Chang, Y. and Hartel, R.W. (2002) Stability of Air Cells in Ice Cream during Hardening and Storage. Journal of Food Engineering, 55, 59-70.

[45] Aguilera, J.M. and Stanly, D.W. (1999) Microstructural Principles of Food Processing and Engineering. 2nd Edition, Aspen Publisher, Gaithersburg.

[46] Walstra, P. (1989) Principles of Foam Formation and Stability. In: Wilson, A.J., Ed., Foams. Physics, Chemistry and Structure, Springer, London, 1-51. https://doi.org/10.1007/978-1-4471-3807-5_1

[47] Daw, E. and Hartel, R.W. (2005) Fat Destabilization and Melt-Down of Ice Creams with Increased Protein Content. International Dairy Journal, 43, 33-41.

[48] Akbari, M., Eskndasi, M.H., Niakosari, M. and Bedeltavana, A. (2016) The Effect of Inulin on the Physicochemical Properties and Sensory Attributes of Low-Fat Ice Cream. International Dairy Journal, 57, 52-55.

[49] Lindamood, J.B., Grooms, D.J. and Hansen, P.M.T. (1989) Effect of Hydrolysis of Lactose and Sucrose on Firmness of Ice Cream. Food Hydrocolloids, 3, 379-388.

[50] Hassan, H.N., El-Deeb, S.A., Mehanna, N.M. and Mashaly, R.I. (1984) Alexandria Science Exchange Journal, 5, 412.

[51] Li, B. and Sun, D.W. (2002) Effect of Power Ultrasound on Freezing Rate during Immersion Freezing Potatoes. Journal of Food Engineering, 55, 277-282.

[52] Mortazavi, A. and Tadabatabaie, F. (2008) Study of Cream Freezing Process after Treatment with Ultrasound. World Applied Sciences Journal, 4, 188-190. 
Submit or recommend next manuscript to SCIRP and we will provide best service for you:

Accepting pre-submission inquiries through Email, Facebook, LinkedIn, Twitter, etc. A wide selection of journals (inclusive of 9 subjects, more than 200 journals)

Providing 24-hour high-quality service

User-friendly online submission system

Fair and swift peer-review system

Efficient typesetting and proofreading procedure

Display of the result of downloads and visits, as well as the number of cited articles Maximum dissemination of your research work

Submit your manuscript at: http://papersubmission.scirp.org/

Or contact fns@scirp.org 